\title{
SIBILIA, Paula. Redes ou paredes: a escola em tempos de dispersão. Rio de Janeiro: Contraponto, 2012.
}

Denise Lotito

Mestre em Língua Portuguesa

e especialista em Gestão e

Produção de E-learning

Trabalha no Núcleo TIC e

Educação do Cenpec

E-mail:_denise.lotito@ cenpec.org.br

\section{NOTA DE LEITURA}

A antropóloga e comunicóloga argentina Paula Sibilia - que há alguns anos atua como professora da Universidade Federal Fluminense - dedica-se aos estudos das relações entre corpos, subjetividades, tecnologias e manifestações midiáticas. Desta vez, resolveu orientar seu pensamento para o complexo território da educação e da escola. Quem ganha com isso são os educadores, não só pela oportunidade de observar escolas e alunos através da lente da antropologia e da comunicação, como também por ter em mãos um texto de leitura clara, fluente e bem cuidado: a editora carioca Contraponto, responsável pela publicação, cuidou com capricho do texto em português e ainda disponibiliza em seu site, de forma gratuita, a introdução e o sumário do livro.

Partindo da compreensão de escola como uma tecnologia de época, sujeita, portanto, a mudanças de acordo com as necessidades e características de cada momento da história - ou, nas palavras da autora, sujeita a um projeto histórico -, o livro começa elucidando as diferenças entre a escola da era moderna e a escola atual para, num segundo momento, deterse na análise e descrição do projeto histórico contemporâneo, ao qual a escola, os jovens e os adultos estão submetidos. Trata-se, assim, de uma obra que enfrenta corajosamente as dificuldades inerentes às análises que têm por objeto a contemporaneidade.

Se ter um método e segui-lo com coerência é sinal de qualidade, então, desse ponto de vista, a análise de Sibilia ganha nota dez. Desde o título e as primeiras linhas, e ao longo de toda a leitura, vemos sendo desenhado um método de análise a que a 
autora se agarra com fidelidade até a última linha. Nem o título escapa a essa coerência, o que nos ajuda a começar por ele para apresentar a obra.

Os dois substantivos que compõem o título são imagens escolhidas pela autora para representar aspectos fundamentais na determinação das subjetividades da era moderna (paredes) e da era contemporânea (redes). Acompanhado do subtítulo "a escola em tempos de dispersão", o título "redes ou paredes" pode nos levar a algumas reflexões. Se entendermos a conjunção "ou” em seu sentido alternativo, então redes e paredes podem ambas estar presentes na escola em tempos de dispersão, de forma alternada: para algumas situações, “redes"; para outras, "paredes". Se "ou” tiver sentido de exclusão, a escola contemporânea terá de escolher entre uma ou outra. E há ainda o sentido de oposição: as redes se opõem às paredes. Ainda que ao longo do livro a autora se preocupe em fazer ressalvas muito sensatas à necessidade de alternância entre momentos de "redes" e de "paredes" para a escola contemporânea, o texto de forma geral parece tender a uma visão de mundo para a qual à realidade são dadas apenas duas possibilidades: ou isto ou aquilo.

Para não deixar nosso leitor em suspenso por mais tempo, convém acrescentar aqui uma breve explicação sobre os termos “redes" e "paredes". As redes dizem respeito à cultura e à sociedade da globalização e da internet, enquanto as paredes fazem referência à sociedade da era industrial, em que o confinamento possibilitado pelas paredes era imprescindível à educação e ao treinamento de cidadãos e trabalhadores úteis ao desenvolvimento econômico capitalista.

Nos primeiros capítulos a autora se dedica a identificar as marcas da escola da era moderna que a tornavam eficiente para o estabelecimento e solidificação do projeto histórico pelo e para o qual foi concebida. Seguindo o raciocínio de oposição que dá forma ao título do livro, os capítulos seguintes vão aos poucos e minuciosamente traçando uma lista de oposições entre a era moderna e a nossa época que, juntas, definem o atual projeto histórico a que estão submetidos os corpos e subjetividades dos séculos XX e XXI.

Uma das oposições marcantes que são apresentadas ao longo do livro diz respeito à distinção entre a subjetividade introdirigida da era do capitalismo industrial e a subjetividade alterodirigida do pós-modernismo, constituintes, respectivamente, do aluno leitor e do usuário midiático. Segundo a autora, essa diferenciação estaria diretamente associada ao fato de que o espaço da intimidade, necessário à leitura e à escrita, vem cada vez mais dando lugar ao espaço da exposição midiática que caracteriza a chamada, por alguns, 
sociedade do espetáculo, em que o silêncio e o isolamento não têm vez. "Em vez da interioridade e concentração requeridas pelo discurso pedagógico, o discurso midiático requer exterioridade e descentramento" ${ }^{1}$, é o que diz Cristina Correa, a quem a autora várias vezes recorre para explicar as subjetividades contemporâneas e a inadequação da escola tradicional a elas. Nessa nova subjetividade, o tipo de pensamento é diferente. Citando Juan Vansen, Sibilia afirma que "os múltiplos estímulos simultâneos e as constantes distrações do mundo contemporâneo provocam 'vivências dominadas pela percepção que se opõem à aprendizagem clássica que exigia a consciência, a memória e a palavra para gerar uma experiência"”2.

Há muitos outros pontos dessa oposição, expostos por Paula Sibilia na construção do seu raciocínio, igualmente importantes. Vivemos em uma sociedade em que o estado cedeu amplos espaços ao mercado e em que a empresa é assumida como instituição modelo que contagia todas as demais, incluindo-se aí a escola. Deriva dessa ideia o fato de que o aluno deixa de ser aluno para se tornar cliente e a lei (Estado) dá lugar à negociação (mercado). A voz do professor, antes imbuída da autoridade que o conhecimento the conferia, passa a ser uma opinião a mais, entre todas as outras. A sociedade disciplinar, que inculcava o autocontrole, dá lugar ao controle externo, exercido pela vigilância. Passamos da escola integradora e homogeneizante aos projetos individuais elaborados para superar concorrentes.

Ao longo das mais de 200 páginas do livro, a autora argentina tenta ser imparcial ao apontar os prós e contras de uma época e outra. Em uma das passagens nesse sentido, podemos ler o seguinte: "Longe de ser vivido como uma mera vitória sobre as antigas opressões, o sofrimento aqui se deslancha quando não se logra a adaptação a esse ambiente excessivamente instável, que implica uma dinâmica de regras precárias e sempre mutáveis, o que suscita uma impressão de inconsistência e falta de sentido".

Ao final, a conclusão é que grande parte dos problemas com que alunos e professores atualmente deparam no exercício da educação formal decorre da insistência do sistema escolar em manter um formato obsoleto para os dias de hoje, bem como da dificuldade de seus sujeitos em compreender qual é o projeto histórico a que a escola e os jovens estão sujeitos e que aceitam perpetuar ou desejam negar.

CORREA, Cristina. Pedagogia y communication en la era del aburrimiento. In:

LEWKOWICZ, Ignacio. Pedagogia del aburrido: escuelas destruidas, familias perplejas. Buenos Aires: Paidós, 2010.

VASEN, Juan. Las certezas perdidas: padres y maestros ante los desafios del presente. Buenos Aires: Paidós, 2008. 
Os educadores que se interessarem pela obra encontrarão nela muitos pontos de reflexão sobre práticas pedagógicas e currículos. Mas uma coisa assusta: se a tese da autora a respeito das subjetividades contemporâneas estiver correta - inclusive a ideia de que estamos passando por uma mutação biológica -, isso significa que livros como o dela, produzidos por subjetividades moldadas com esmero na tradição da cultura letrada, coerente com o projeto histórico dos séculos XVIII e XIX e parte do XX, estão em vias de extinção. Sugiro degustar enquanto é tempo...

RECEBIDO: Março de 2014.

APROVADO: Abril de 2014. 